\title{
The Evolution of Researchers' Bibliography: From Systematic Organization to Citation
}

\author{
Viviane Couzinet \\ ORCID 0000-0003-4807-2014 \\ LERASS, University of Toulouse III Paul Sabatier - IUT, France \\ Regina Marteleto \\ ORCID 0000-0002-3439-0217 \\ Brazilian Institute of Information in Science and Technology, Rio de Janerio, Brazil \\ Icléia Thiesen \\ ORCID 0000-0002-3137-8933 \\ Federal University of the State of Rio de Janeiro, Brazil
}

\begin{abstract}
Purpose/Thesis: This paper analyses the publications of two authors from different countries through a number of citations identified by Google Scholar. Jean Meyriat and Edson Nery da Fonseca are outstanding researchers in France and Brazil, respectively, both contributing to the formation and advancement of information science in their countries. The "traditional" bibliography and the development trajectory of their scientific achievements were considered in this analysis.

Approach/Methods: The analysis of the researchers' publications identified by Google Scholar based on their names helps to understand the role that search engines play in the evaluation of science and its effect on information seeking and in the evaluation of the scientific production. The qualitative research is based on a bibliological analyses focusing on the way in which the written production of the selected authors is reported and highlighted. The carried out study is exploratory in nature, so it proposes to raise questions and to emit hypotheses that could suggest directions for further research.

Results and conclusions: The uniformity of controlled metadata used in traditional bibliographies make it possible to follow the progress of an author's thought. The same is true of other activities he has performed in and out of the field and, it is also true for what has been produced about this author. Searching for information in Google Scholar can show a researcher's production and publications about her/him in the order of citations but not in the order of the progress of the researcher's scientific achievements or development of research focused on these achievements. Placed in the context of the analysis of the scientific field as it was defined by Bourdieu (1976), the observation of the visibility of the production Jean Meyriat and Edson Nery da Fonseca, two major actors in information science in France and Brazil , by Google Scholar, shows a tendency to underemphasize the role they played.

Practical implications: The functioning of the scientific field has specific effects on the production of research. The search engines such as Google Scholar, made the research output more accessible on Internet. However, the criteria they prioritize, i.e., the number of citations, ignores important aspects of a scientific career. Qualitative analysis that considers the networks of sociability and the development trajectory of researchers' scientific achievements may reveal relevant contributions to their scientific field.

Originality/Value: The results reveal the importance of research methods that combine qualitative and quantitative procedures, thus avoiding the risks of rendering scientific careers invisible.
\end{abstract}




\section{Keywords}

Bibliography. Edson Nery da Fonseca. Google Scholar. Information science. Jean Meyriat. Scientific field.

Received: 5 May 2019. Reviewed: 13 July 2019. Revised: 13 September 2019. Accepted: 6 December 2019.

\section{Introduction}

It is commonplace knowledge that bibliography has been used to assess an author's scientific production since the 2nd century AD when Galen published De libris propiis. The rules of bibliographic writing have evolved over with an aim to identify sources of information as to make them more available for sharing. For this reason, the work of French scholars and librarians is different from the work associated with the book science tradition, as well as more generally, with the written text science and bibliology. Both specialized and general bibliographies meet the requirements of an internal organization which provides access to the needed documents and defines which subject areas are covered by the given bibliography.

A bibliography which records a single researcher's production might be organized with a specific goal in mind, e.g. it may highlight his or her expertise in the subject, or association with publications recognizable in the researcher's community. However, search engines which have taken over printed bibliographies, organize their records according to different measures of visibility, such as the number of citations. The object of a search is also the basis for the evaluation of the researcher's production. At this point, it is worthwhile to ask what view these engines afford us, and how do they change scientific practices.

To answers these questions, we examine the modalities of the functioning of the scientific field (Bourdieu, 1976), and define the bibliography and the systematic knowledge organization it proposes (Meyriat, 1957; 1993). The analysis of the record of researches' publications provided by Google Scholar will show us the role that search engines play in the evaluation of scientific production and how they change both the process of evaluation and of information seeking.

\section{Literature review}

\subsection{Scientific field}

The notion of «scientific field» was developed by Pierre Bourdieu. Bourdieu argued that to understand an intellectual production, analysis must not be limited to the content and social context of production (Marteleto \& Carvalho, 2015). It must take into account the intermediate universe into which the agents (as Bourdieu named actors in the field) are incorporated. This universe is a social and institutional world that obeys its own laws (Bourdieu, 1997). It is a microcosm with a certain autonomy but it does not escape the macrocosm which surrounds it. To understand the processes of information production and dissemination in a field of knowledge, or a scientific field, it is then necessary to take into consideration the common language, classifications and agents that are constitute an 
epistemic community, as well as their links with the outside world and with other social fields (Nascimento \& Marteleto, 2007).

The scientific field is a place of struggle for scientific domination. It shares fundamental concepts, methods, verification procedures and tacit norms which comprise a «scientific habitus». The scientific authority defined as a technical capacity and a social power is inseparable from the recognition given by peers, who are also competitors. This assumes that the recognition of value, i.e., prestige, scientific authority, depends on other agents who, in order to grant it, will examine and discuss the production. Thus, groups in contact draw their legitimacy from their strength, the perpetuation of which is an important aspect. Thus achieved, the scientific authority is a symbolic capital (Bourdieu, 1976).

There are two kinds of capital in the scientific field: institutional and institutionalized. The former refers to the eminent positions and the power over the means of production; the latter refers to the personal prestige obtained by the contributions to the progress of science (Bourdieu, 1997). Productivity and prestige are part of a trajectory constituted by an academic origin (high school, prestigious university), which fosters academic aspirations and provides opportunities for development in that direction. The social capital is also acquired through scientific output, particularly in scientific journals evaluated by peer-competitors (Bourdieu, 1976). Therefore, an analysis of the evolution of a researcher's production should begin with a record which identifies it: a bibliography.

\subsection{Bibliography}

The word bibliography has two meanings. It may refer to a list recording the written production of a particular person, country, time period or theme, or to the activity of developing the notes which constitute such a list. Various types of bibliography in the first sense have been distinguished according to their geographic coverage - international or national, to their theme, the field covered by their content or by their selective or exhaustive elaboration method (Malclès, 1984). Although for a long time it was reserved only for books, since then it has been extended to all forms of writing (Meyriat, 1993) and its role in knowledge circulation has been emphasized (Couzinet \& Fraysse, 2018; Malclès 1984; Meyriat, 1993; Provansal, 1997). In France, the production of bibliographies constitutes a separate profession, and it is considered as an art. Meyriat (1993) and Estivals (1993) introduced an understanding of the "science of writing", i.e. bibliology, with bibliography as one of its methods. However the separation between bibliology and bibliography is not always maintained (McKenzie, 1991), with both bibliography and bibliology occasionally considered as science.

Bibliographical notes record data about the author, the title, the source, the date and the pagination of the text. They may be supplemented by an abstract summary or other comments. Bibliography is presented in the alphabetical order by the authors' last names, or by themes. Indexes multiply the possible entries. Bibliographies are considered to be the ancestors of data bases. The computer has facilitated the multiplication of the entries while preserving the quality of the data. Bibliographical records facilitate organization of knowledge and thus support the researcher's work. 


\subsection{Research evaluation}

A researcher's scientific production as recorded by a bibliography goes through a critical evaluation of the peer-competitors before being accepted by a mediator (Bourdieu 1976). "Pure" scientific capital is acquired mainly through recognized contributions to the progress of science, inventions, or discoveries" (Bourdieu, 1997, 29), circulating in the scientific field through media. It is then possible to establish the list of publications for each researcher to disseminate his personal contribution. The tools for the circulation of science, the researchers' bibliographies, are therefore also a means to position a researcher on a scale of production and thus to evaluate it quantitatively. In this way, a «capital of authority» (Bourdieu, 1976) is built.

Nevertheless, the functioning of the scientific field affects the way the research is conducted. This is what Merton called "the Matthew effect in science", which refers to a phenomenon where the greater the scientific capital is, the more the scientific production is accepted by the peers (Merton, 1968). This is particularly relevant to ordering articles in journals to produce syntheses. The authority of the requested author contributes to the journal's reputation.

Currently, researchers' production circulates on the Internet through search engines. How do they make the researchers' production visible? To answer this question, we examined the results of searches conducted using Google Scholar.

\section{Research methods}

\subsection{Google Scholar}

Google Scholar was launched in November 2004 by Google as a search service for research journal articles (mainly but not exclusively peer-reviewed), scientific books and academic theses. It also indexes conference proceedings, guides, reports and other texts researchers may produce. It is possible to choose the date, sort by relevance, to include patents and quotes, and to create an alert. The results provide the title, the author's first and last name (sometimes confusing the two), the number of citations received, with an option to access the document which cites the original text. Furthermore, it is possible to record the data in a personal library, to write the following reference to specific standards and to access publications that Google assumes are of interest. A link to the original text, if it has been deposited in an archive, is present. Often a short extract from the summary accompanies the record. A notice may indicate a change of language or an editorial unavailability. In this it is difficult to establish from where the enumerated data is coming (Rovira et al., 2018), even if clear agreements have been reached with libraries.

The records are ranked according to the number of citations received. The tests we have conducted show many errors, which suggest that the ranking is untrustworthy. The top results do not give a comprehensive view of the author's scientific output.

A progress report has been prepared by Martin-Martin et al. (2017), who in a recent research based on a bibliometric analysis conducted on 64000 records, questioned the possibility of using Google Scholar for identifying the most cited documents. They showed 
that the publication date of the documents cited has a low impact on the classification and that the language of the documents does not affect the classification either (Martin-Martin et al., 2017).

Google Scholar is well-adapted to our research as the variety of the documents it indexes corresponds to the various forms of publications by the authors' whose research output is analyzed. It should be stressed that in the time when they published their most influential works, there were only few journals in information science in France and Brazil.

For the purposes of this study, the observation consisted of searching by author's name in French and Portuguese records from any time period, sorted according to their relevance. In order to make the analyzed problems more significant, we have chosen two scholars as well as practitioners who contributed to development of information science in France and in Brazil. Each has a well-established international reputation. This research work has been undertaken within a Franco-Brazilian cooperation network Mediations and Social Use of Knowledge and Information (MUSSI).

\subsection{A bibliological analysis}

The research is based on a bibliological analysis. It analyzes the way in which the written production of the selected authors is reported and highlighted. The approach is comparative, as it takes into account the representation modes of the bibliographic lists described as "traditional" - the printed bibliographies and the bibliographical databases and the data available through Google Scholar. The study we have carried out is exploratory in nature: it raises questions and suggests hypotheses that could inspire further research.

This research is qualitative. The context of the authors' scientific production is a point emphasized in the analysis, our initial hypothesis being that although science is increasingly globalized, a researcher who has only a limited geographical recognition can nevertheless play a major role in the development of a science because of other factors, which we take into consideration. Our central question is whether such research needs to be continued.

\subsection{Selected authors}

Jean Meyriat (1921-2010), a former student of the Ecole Normale Supérieure, had been a professor at the Insitute d'Études Politiques (IEP) and Director of Studies at the Ecole Pratique des Hautes Études (EPHE) in Paris. Since the 1950s he had been working with the UNESCO on documentation issues in his capacity as Director of Documentation Services at the Fondation Nationale des Sciences Politiques (FNSP). Within the Center, which under his leadership became a center for library and documentation, he organized production of many bibliographic tools drawn from journals articles, which at the time had been an unprecedented practice. These bibliographic tools covered the major disciplines at the IEP, international law and comparative law. In 1952, he co-founded the first FNSP research laboratory, the Center for the Study of the International Relations Studies, which operates to this day attached to the National Scientific Research Center (Fr. Centre national de la recherche scientifique - CNRS). From 1961 to 1965, Meyriat chaired the Mediterranean Social Science Research Council.

In addition to his documentation-oriented activities, Meyriat was a lecturer at the Institute of Advanced Studies in Latin America, where he directed many doctoral theses on 
the Latin American politics. He had been a visiting professor at the Colegio de México. He was convinced that library and documentation activities must be founded on research, as the techniques used by the information professionals "depend, for their dynamism and thriving and acquirement of a fundamental knowledge" (Meyriat, 1994, 42). Accordingly, he added theoretical reflection to this other achievements, and taught a course "Theory of Documentation" at the request of the historian Fernand Braudel, from 1962.

His work focused on the development of a social theory of the document, consolidation of the vocabulary of this new discipline in France, establishment of its research methods, and supervising of multiple doctoral theses. His contributions to the field of law, Latin America studies and information science were tremendous. He gave priority to the latter from 1975-1980 onwards by leading a research group on the written word and document (1979-1982) with Robert Estivals, then a young doctor working on book history and a researcher associate at the CNRS. The work they had undertaken gave rise to a major text, Document, documentation, documentology (Meyriat, 1981), which marked France's entry into information science. This seminal text, which serves as a reference for all the French social approaches to the document, has recently been translated into Portuguese by Brazilian colleagues (see Meyriat, 2016). A part of Jean Meyriat's writing has been re-issued with his biography and testimonials of people who worked with him, and a research study, which highlighted his action or developed his reflection, (Couzinet \& Rauzier, 2001). According to the bibliographical record from the book, Meyriat had published 127 texts (39 journal articles, 22 contributions in conference proceedings, eight book chapters, six professional guides, 48 articles in the International Encyclopedia of Bibliology, four articles in the Encyclopedia of Information and Documentation). In addition, he had produced standards, courses for the Commission of the European Communities, reports for various academic bodies or for UNESCO, training programs and extensive bibliographic work in political science. He had been the founder of several repertories and bibliographic journals in this discipline. He was also responsible for the creation and animation of several scientific societies, including the International Association of Schools of Information Science (AIESI). Its international action has been recognized by UNESCO which awarded him with the Aristotle Gold Medal (1992) for its contribution to international scientific cooperation and by Professor PN's Foundation Kaula (1992) who awarded him with the gold medal as a recognized world-wide scholar for his entire work in information science.

Other publications were found after the publication of Jean Meyriat, théoricien et praticien de l'information-documentation (Couzinet \& Rauzier, 2011) and Meyriat continued to publish until his death in 2010. In particular, an article published in the journal Sciences de la société extended his reflection on the document by proposing a new analytical method (Meyriat, 2006).

Various meetings had marked his career, especially the one with Robert Escarpit and Robert Estivals as they were preparing a collective work Le Livre français (Cain \& Martin, 1972) ${ }^{1}$. Together, they began a scientific and institutional construction of an academic

1 This book was edited by Julien Cain, a historian, director of the Bibliothèque nationale de France and by Henri-Jean Martin, also a historian. It was published in 1972 by the National Printing Services. Jean Meyriat whose activity and theoretical reflection had then centered on journals is the author of a chapter devoted to the "non books" (319-331). 
discipline named information and communication sciences, combining the information science and the science of communication.

Meyriat had been involved in the institutionalization of information and communication sciences (in 1975) and had created training courses from undergraduate to doctoral level (Couzinet, 2017). In particular, he chaired the National Council of Universities (Fr. Conseil national des universités - CNU), a body that developed an understanding of the "science of writing", i.e. bibliology, with bibliography as one of its methods, defined the contours and the criteria of membership of the discipline, managed the careers of academics in the discipline and awards qualifications, i.e. the possibility of applying for a post in higher education after the doctorate. Moreover, he established links between university education and the professional bodies (Couzinet, 2000; 2017). He is considered to have been a major theoretician in IS and documentation in France.

Information science in Brazil derived from a broad sociotechnical network of multiple institutional actors in the cross-conformation of the discipline. This network consisted of researchers and information professionals, but also of publications, meetings, agency programs, institutional policies of state agencies. As a teacher, writer and librarian, Edson Nery da Fonseca (1921-2014) had been an important node of this network.

He graduated as a librarian at Biblioteca National do Brasil in Rio de Janeiro in 1946. Devoted to the teaching of "disciplina do livro", he was interested in the training of an interdisciplinary librarian with technical knowledge and a cultural base which he considered essential. During his long career, he worked in various institutions, such as the Brazilian Institute of Bibliography and Documentation (now IBICT - Por. Instituto Brasileiro de Informação en Ciência e Tecnologia), where he headed the bibliography department. At the new University of Brasilia, he was a professor and the founder of library science course and the founder of the Central Library. He witnessed the emergence of the information science in the early 1970s, when a master-research level training was created at IBICT, as well as the establishing of the journal Ciência da Informação, which consolidated the emerging field (Thiesen, 2010). He was a great critic of library practices, which he said ignored the advances and transformations of scientific practices; he argued that one

must consider library science as one of the sciences of information and consider all knowledge from an interdisciplinary a point of view (Fonseca, 1988, 102) 2 .

In addition to being a librarian and a bibliographer, a teacher and a columnist, Fonseca was an intellectual. He belonged to a network of intellectuals from different institutions and of different profiles. His production, however, was not limited to the field of library science, documentation, and information science. His intellectual curiosity had enabled him to be involved in a network of sociability made up of writers, filmmakers, journalists, academics and had inspired him to activities beyond libraries and universities. Several authors contributed to the book published on his eightieth birthday, edited by Mota and Verri, including the eminent sociologist Gilberto Freyre who entitled his tribute $A$ Master of Masters (Mota \& Verri, 2001).

Fonseca's professional experience was further enriched by his work at the National Book Institute (Por. Instituto Nacional do Livro - INL), the Brazilian Association of Technical

\footnotetext{
${ }^{2}$ Own translation [IT].
} 
Standards (Por. Associação Brasileira de Normas Técnicas - ABNT) and the Joaquim Nabuco Foundation in Recife. However, he never forgot his relationship with the northeast region, where he established libraries and found library courses.

The primary themes of Fonseca's works are bibliography and its precursors, documentation, teaching history of librarianship and scientific information. His long public life had allowed the author to witness many changes in these domains of knowledge which he had influenced over fifty years he had been active.

Fonseca published a number of works between 1942 and 2001, according to a repertoire compiled by the librarians from Pernambuco State, Cordelia Cavalcanti and Lucia Gaspar and presented by Mota and Verri (2001). Their book showcases the extent and variety of Fonesca's output, as it refers to 15 books, 20 booklets, 73 collaborations in individual and collective works, eight entries in consultation papers, 23 prefaces, afterwords, presentations and introductions, 198 articles, bibliographies and magazines, 420 newspaper collaborations, four publishers, 20 individual and collective works organizations, seven interviews, four discographies, three participations in filmography, and 103 items published about Fonesca.

We are therefore dealing with two quite different figures, both of whom had made major contributions to the evolution of training and research in their respective countries.

The analysis of the production of Meyriat and Fonseca in Google Scholar was conducted according to the criteria stated above. The order of the retrieved bibliographic descriptions is random. For example, the most cited text of Meyriat, which is a major contribution to the information science, appears only in the 8th position on the days of the search. We checked the first pages of the results provided by Google Scholar between April 16th 2019 and April 30th, and on May 1st 2019. The observations made raised some questions.

\section{Results and discussion}

\subsection{Scientific controversies and fashion effects}

Unlike the bibliography in its old form, which exhaustively or selectively lists the production of a researcher in a chronological order which enables the reader to follow the progression of the work on a given theme, Google Scholar gives priority to the works which are cited by others. This preference is problematic. The reference is isolated from its citation context: we may ask then if it is a "true" reference, i.e. bearing a call to an author of which one recognizes the expertise or has produced a remarkable breakthrough in a field, is it a negative criticism, that is to say a rejection of the results based on a method equally questionable? Is it a "recognition quotation" of an author citing or the desire to fit into a movement? Scientific controversies inspire many works which inflate the number of citations.

Furthermore, identifying the status of an issue, or publishing a book of synthesis lead to a large number of citations. They are a part of readings prior to any research, and therefore they are cited more often than other works in the field. Some research topics are considered as more "fashionable", e.g. the research of environmental issues has been very popular recently, and as such, it has been attracting more funding. Although we do not intend to dismiss the urgent need to study the environment, we question if it is comparable with the fundamental research aiming to establish a discipline. 


\subsection{Globalization and marginalization}

If the professional field and the scientific field of information are related, to be in a recognized academic discipline, to train high-level practitioners and researchers at the university, it is necessary to think about their theoretical foundations. For the last three decades of the 20th century, industries and the society in general have demanded a political and organizational response to their increasing need for scientific and technical information. The development of computer science led to proliferation of studies which applied it to practical problems using bibliometric analysis. At the time they were well received by journals and on conferences and seminars, while qualitative or theoretical analyzes of research output were marginalized. Meyriat's project in France was to build information science as academic discipline, to ensure its position, build its base, produce theories, develop its concepts and methods, which was the most important issue between 1975 and 1990 . However, as more scholars move into bibliology from the hard sciences, especially physics, the increasing trend has been to overlook the theoretical part of scientific work. This could explain why the works of the scholars being the subject of this study are cited only rarely in Google Scholar (1710 citations in political science, law and information science for Meyriat, a researcher with a 46-year career) and reflects the Matthew effect in science (Merton, 1968). The number of citations of Fonseca's work retrieved by Google Scholar is much bigger (3080). However, he was active on many fields, as librarian-bibliographer, teacher, columnist, and intellectual who was a part of a wide social network. His production had not been limited to the field of librarianship and information science.

\subsection{Splitting up or career path}

The uniformity of the controlled metadata of traditional bibliographies make it possible to follow the progress of an author's thought. The same is true of all other activities he has conducted inside and outside the field and, of what has been produced about this author. A search conducted through Google Scholar can give a view of the author's work, ordered by a number of citations, but not a view of how the author's though has progressed. Thus it is very difficult to draw a complete research activity by searching in Google Scholar.

The increasing order of the citations, even if not always respected, can confuse the reader. Results of the search for Meyriat's works present a statistics guide as one of his cited publications. It appears in the first position (with 76 citations), while his article about document, with 124 citations appears in the eighth position. In results for Fonseca's work, his publication with $\mathrm{G}$. Freyre, including some recipes for cooking, are presented between the most cited. In both cases, retrieved data is the mark of various interests of these two authors related to their belonging to their time, to the professional, the academic and intellectual world. This may lead to confusion: for example, the first item in Google Scholar page for Fonseca, a book Açúcar: uma sociologia do doce, com receitas de bolos e doces do Nordeste do Brasil (Sugar: a sociology of sweets with cake and candy recipes from Northeast Brazil) ${ }^{3}$, authored by sociologist Gilberto Freyre, had its first edition in 1939 and has been reissued

3 Freyre: Açúcar: uma sociologia do doce, com receitas de bolos e doces do Nordeste do Brasil. São Paulo: Cia das Letras, 1997 (1939). 
over the years. In this book, the author continues to analyze the importance of Portuguese, indigenous and African influences on the emergence of Northeastern Brazilian cuisine, and emphasizes the effect of the sugarcane monoculture on the socio-cultural creation of the state of Pernambuco, where it originated. Freyre's close friend of many decades, Edson Nery da Fonseca is the author of a biobibliography of Freyre attached to the work. He has been listed in Google Scholar as a co-author and not as a contributor, what a traditional bibliography would have corrected.

Nevertheless, Fonseca's most cited publications refer to the history of librarianship (197 citations), bibliography and bibliometric (190 citations), which have recently become timely as la result of the current interest in research related to the information science. He had commitments to politics and institutions. As far as Meyriat is concerned, the negligible number of references to his scientific work in information science results from the lack of the visibility of the journal where he had published most of his writing. Coming from a Grande Ecole, he was a professor in an institution close to the center of political power: this connection made the communication and information science, which development he led, more recognized and prestigious. As Bourdieu says, everything happens only if his "institutional scientific capital" (Bourdieu, 1976) becomes recognized. Fonseca was closer to the profile of the academic intellectual, who united scientific aspirations with information-based practices, as he was actively involved in library policies and programs in his state of Nordeste, and participated in the creation of new lines of research for the new discipline in Brazil.

The scientific contribution of these two precursors of the information field in France and Brazil, seems to be forgotten in the time of citation-counting. Publication in journals that have become minor or in less known or vanished publishing houses, books that are out of print, is superseded by the current circulation on the Internet. Only fragments of the journey are taken into consideration. Therefore, we are right to ask if their invisibility in Google Scholar means that these authors have been completely forgotten.

\section{Conclusion}

Taking into account the differences between the French and Brazilian experiences, we may say that the two authors are considered to be major founders of the field of the documentation and in information science. If, as Martin-Martin et al. argue,

Google Scholar can be used to reliably identify the most highly-cited academic documents. Given its wide and varied coverage, Google Scholar has become a useful complementary tool for bibliometrics research dealing with the identification of the most influential scientific works in the state of our research (Martin-Martin et al., 2017, 162),

then the disorder of the classification and the writing of the bibliographic records do not accurately represent the fundamental role played by figures nowadays recognized in their discipline.

The evaluation of their scientific output cannot be limited to quantitative criteria. It is necessary that the works published by barely visible publishers are better known; they are analyzed and cited by researchers interested in the themes to which they have devoted themselves, in particular to develop the state of the art; also to work and research questions 
that show developments and place current research within a long disciplinary time frame. The role of Meyriat and Fonseca in the establishment of the field of information science is still to be examined and analyzed.

The questions raised by this qualitative research show that a further study will increase the visibility of the role played by Fonseca and Meyriat in the institutionalization of the information science in France and Brazil, its training processes, the sociability network in the field and scientific debate inspired by their ideas. Other scholars who have now passed away might be the subject of similar studies, which will be a significant contribution to the historical study of the information science.

\section{References}

Bourdieu, P. (1976). Le champ scientifique. Actes de la recherche en sciences sociales, 2(2/3), 88-104.

Bourdieu, P. (1997). Les usages sociaux de la science: pour une sociologie clinique du champ scientifique. Paris: INRA Éditions.

Cain, J., Martin, H.-J. (eds.). (1972). Le Livre français. Paris: Imprimerie nationale.

Couzinet, V. (2000). Médiations hybrides : le documentaliste et le chercheur. Paris: ADBS Éditions.

Couzinet, V., Rauzier, J.M. (collab.). (2001). Jean Meyriat, théoricien et praticien de l'information-documentation. Paris: ADBS Éditions.

Couzinet, V. (2017). Construction des sciences de l'information et de la communication françaises: rôle de Jean Meyriat (1921-2010). In: W. Mustafa El Hadi (ed.). Fondements épistémologiques et théoriques de la science de l'information-documentation. Actes du 11e colloque ISKO France 2017 (40-58). London: ISTE.

Couzinet, V., Fraysse P. (2018). Bibliographie et bibliographes en France: des revues pour la circulation de la science. Bibliothecae.it, 7(2), 172-197.

Estivals, R. (ed.) (1993). Les sciences de l'écrit: Encyclopédie internationale de bibliologie. Paris: Retz.

Fonseca, E.N. da. (1988). Ser ou não ser bibliotecário e outros manifestos contra a rotina. Brasília: ABDF.

McKenzie, D. F. (1991). La bibliographie et la sociologie des textes. Paris: Cercle de la librairie.

Malclès, L-N. (1984). Manuel de bibliographie. Paris: Presses Universitaires de France.

Marteleto, R., Carvalho, L. (2015). Health as a Knowledge Domain and Social Field: Dialogues with Birger Hjørland and Pierre Bourdieu. Knowledge Organization, 42(8), 581-590, https://doi. org/10.5771/0943-7444-2015-8-581

Martin-Martin, A., Orduna-Malea, E., Harzing A-W, Delgado Lopez-Cozar E. (2017). Can We Use Google Scholar to Identify Hightly-Cited Documents? Journal of Informetrics, 11(1), 152-163, http://dx.doi.org/10.1016/j.joi.2016.11.008

Merton, R.K. (1968). The Matthew Effect in Science. Science, 159(3810), 56-63.

Meyriat, J. (1957). Rapport sur les principes généraux du travail bibliographique international [online] UNESCO Digital Library [06.12.2019], https://unesdoc.unesco.org/ark:/48223/pf0000127383_fre.

Meyriat, J. (1981). Document, documentation, documentologie. Schéma et schématisation, 14, 51-63.

Meyriat, J. (1993). La bibliographie. In: R. Estivals, J. Meyriat, F. Richaudeau (eds.), Les Sciences de l'écrit, encyclopédie internationale de bibliologie (548-553). Paris: Retz.

Meyriat, J. (1994). Y a t'il une place pour une théorie de la documentation? Revue de bibliologie, 40, $39-45$.

Meyriat, J. (2006). Pour une compréhension plurisystémique du document (par intention). Sciences de la société, $68,11-28$.

Meyriat, J. (2016). Documento, documentação, documentologia. Perspectivas em Ciencia da Informação, 21(3), 240-253, http://dx.doi.org/10.1590/1981-5344/2891 
Mota, A., Verri, G.M.W. (2001). Interpretação de Edson Nery da Fonseca. Recife: Bagaço.

Nascimento, D. M., Marteleto, R. (2007). Social Field, Domains of Knowledge and Informational Practice. Journal of Documentation, 64(3), 397-412, https://doi.org/10.1108/00220410810867605

Provansal A. (1997). Bibliographie. In : S. Cacaly (ed.), Dictionnaire encyclopédique de l'information et de la documentation (67-71). Paris: Nathan.

Rovira, C., Guerrero-Salé, F., Codina, L. (2018). Las citas recibidas como principal factor de posicionamento SEO en la ordenación de resultados de Google Scholar. El Profesional de la información, 27(3), 559-569, http://dx.doi.org/10.3145/epi.2018.may.09

Thiesen, I. (2010). L'information entre réalité et imaginaire: approches historiques au Brésil. In: V. Couzinet, R. Marteleto (eds.), Médiations documentaires: entre réalités et imaginaires: actes de la première journée scientifique internationale du réseau MUSSI (53-70). Toulouse: Université de Toulouse 3.

\title{
Ewolucja bibliografii badaczy: od systematycznej organizacji do cytowań
}

\begin{abstract}
Abstrakt
Cel/Teza: Artykuł analizuje publikacje naukowe dwóch badaczy z różnych krajów, wykorzystując cytowania zidentyfikowane przez Google Scholar. Jean Meyriat i Edson Nery da Fonseca byli wybitnymi naukowcami we Francji i w Brazylii. Obaj mieli duży wkład w kształtowanie i rozwój informacji naukowej i bibliotekoznawstwa w swoich krajach. Tradycyjna bibliografia oraz kierunki naukowego rozwoju obu badaczy zostały opisane w niniejszym artykule.

Koncepja/Metody badań: Przeprowadzono analizę publikacji obu badaczy na podstawie danych z Google Scholar, co pomogło prześledzić rolę, jaką odgrywają wyszukiwarki w ewaluacji nauki i ich wpływ na wyszukiwanie informacji oraz ocenę dorobku naukowego. Analiza jakościowa opierała się na analizie bibliologicznej, skupionej na sposobie, w jaki piśmiennictwo obu autorów jest przedstawiane i które elementy są uwypuklane. Niniejsza analiza ma charakter poszukiwawczy, sugeruje kolejne pytania badawcze i hipotezy, które mogą wskazać kierunki dalszych badań.

Wyniki i wnioski: Jednolite, kontrolowane metadane stosowane w tradycyjnych bibliografiach pozwalają na prześledzenie rozwoju myśli badawczej danego autora. To samo dotyczy innych podejmowanych przez niego aktywności, zarówno w ramach własnego pola badawczego, jak i poza nim, a także innych publikacji, które danego autora dotyczą. Wyszukiwanie w Google Scholar daje dostęp do informacji na temat publikacji autora i publikacji jego dotyczących wyłącznie w kolejności liczby cytowań, a nie w porządku pozwalającym na prześledzenie naukowych osiągnięć autora czy rozwoju jego badań. Obserwacja widoczności dorobku dwóch wybitnych informatologów, Jean Meyriata (Francja) i Edsona Nery de Fonesci (Brazylia), na podstawie analizy wyszukiwań w Google Scholar, usytuowana w kontekście analizy pola badawczego, zdefiniowanego przez Bourdieu (1976), ukazuje tendencję do umniejszania roli, jaką odegrali.

Zastosowanie praktyczne: Sposób funkcjonowania danej dyscypliny badawczej wpływa na prowadzenie w niej badań. Wyszukiwarki, takie jak Google Scholar ułatwiają dostęp do opisów rezultatów badań naukowych. Jednakże kryterium, jakie stosują do szeregowania wyników, czyli liczba cytowań, skutkuje pominięciem innych ważnych aspektów dorobku naukowego danego autora. Analiza jakościowa, obejmująca powiązania między autorami oraz kierunki naukowego rozwoju, może ukazać właściwy wkład danego autora w rozwój dyscypliny.

Oryginalność/Wartość poznawcza: Przedstawione wyniki badań uwypukliły znaczenie stosowania w procesach wyszukiwawczych zarówno metod ilościowych, jak i jakościowych, aby zapobiec ryzyku pominięcia różnych aspektów dorobku naukowego.
\end{abstract}




\section{Słowa kluczowe}

Bibliografia. Edson Nery da Fonseca. Google Scholar. Jean Meyriat. Nauka o informacji. Pole badawcze.

VIVIANE COUZINET is Professor emeritus in Information and Communication Sciences at the University of Toulouse III-Paul Sabatier. She holds a PhD in Information and Communication Sciences from the University of Bordeaux III Michel de Montaigne, France. Her main areas of interest are the mediation process in hybrid contexts (scientific mediation and documental mediation); information representation in "mediators" objects and informational practices; knowledge organization as "mediators" objects of knowledge; social theory of document; documentologic approach (methods, concepts and theorization)

Contact to the Author:

viviane.couzinet@iut-tlse3.fr

Laboratoire d'études et de recherches appliquées en sciences sociales (LERASS)

Equipe: Médiations en information-communication spécialisée (MICS)

Université Toulouse III-Paul Sabatier-IUT

115 B Route de Narbonne

BP 67701

F-31077 Toulouse Cedex 4, France

REGINA MARTELETO, PhD, is a tenured researcher at the Brazilian Institute of Information in Science and Technology (IBICT) and a core member of the postgraduate program in Information Science at the Federal University of Rio de Janeiro (UFRJ). She is the coordinator of Culticom, a research group on Culture and Info-communicational processes: www.culticom.org. Her main areas of interest are: culture and information; knowledge, information and society; information and communication on health; info-communicational mediation in social networks; the subject, interpretations, and languages of information in contemporaneity; social theory, epistemology and interdisciplinarity in the field of information.

Contact to the Author:

regina.mar@ibict.br

PPGCI/IBICT-UFRJ

Rua Lauro Muller, 455 - 4o. andar

CEP 22290-160 - Rio de Janeiro, RJ, Brazil

ICLEIA THIESEN, PhD, is a tenured professor and researcher of Information Science at the Federal University of the State of Rio de Janeiro (UNIRIO) at the Department of History. Her main areas of interest are: relations between information, memory and history; sensitive documents in exception regimes; institutional memory; political uses of the past; info-communicational devices aimed at retrieving sensitive information in archives.

Contact to the Author:

icleia.thiesen@unirio.br

Universidade Federal do Estado do Rio de Janeiro (UNIRIO)

Av. Pasteur, 458 - Prédio do CCH - subsolo - sala 20

CEP 22280-240 - Urca - Rio de Janeiro, Brazil 